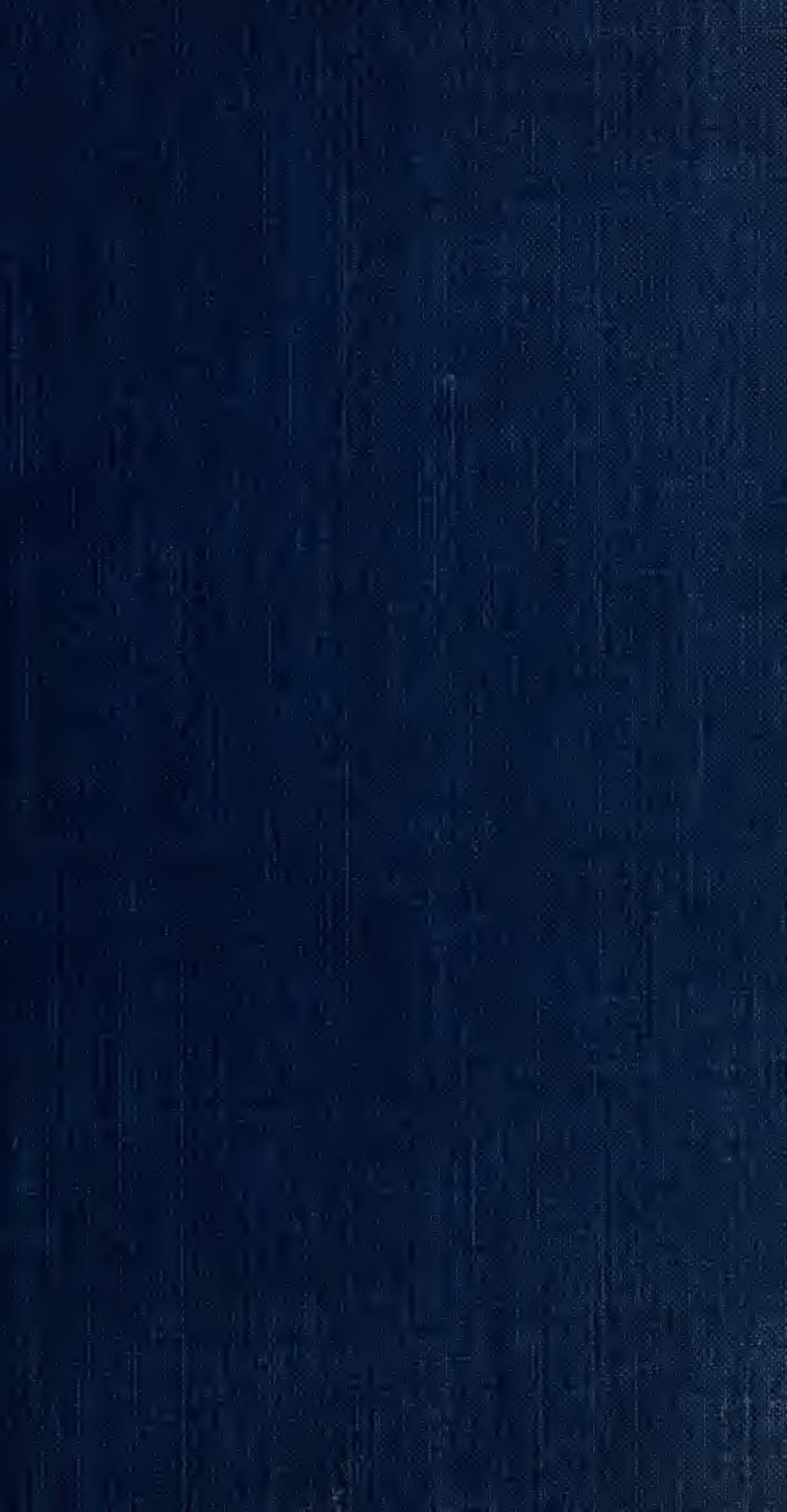




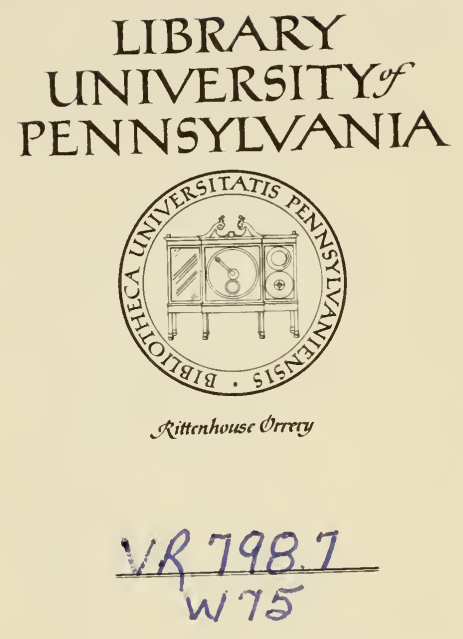

GIFT OF FAIRMAN ROGERS 


\section{University of Pennsylvania Libraries}

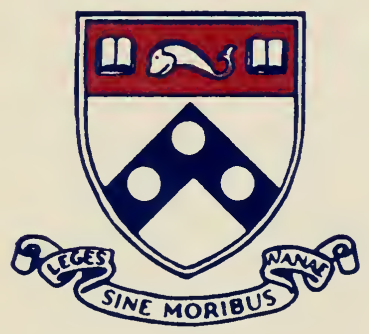

Annenberg Rare Book and Manuscript

Library 
Digitized by the Internet Archive in 2009 with funding from

Lyrasis Members and Sloan Foundation 




\section{H 0 R S E T R A I N I N G}

UPON NEW PRINCIPLES;

LADIES' HORSEMANSHIP, AND TIGHT LACING.

NICHOLAS WISEMAN.

THIRD EDITION:

L O N D O N :

PRINTED BY W. CLOWES AND SONS,

14, CHARING CROSS.

1852. 



\section{E D I C A T I $0 \mathrm{~N}$.}

I want a Patron! What is a Patron? "One," Dr. Johnson says, "who looks with unconcern on a man struggling for life in the water, and when he has reached ground encumbers him with help." I want no such patron-I want no help-I want admirers of horses, those who are most admired when seated upon their horses' backs. To your gracious Majesty Vic'roria, Queen of Great Britain and Ireland,- -and to the Ladies of England, this unpretending little Pamphlet is very respectfully dedicated,

By their most devoted,

And most obedient Servant,

Nicholas Wiseman. 



\section{P R E F A C E.}

$W_{E}$ have been implored to look down from Olympus upon the following little Tract of Nicholas Wiseman, and find it to contain improved principles for Training and Educating the Horse, compared with those we ourselves have practised, and for which we were deified, and had statues erected to our names. We recommend this Pamphlet to the Sodalitium Equestre, or Jockey Club, and to all who take delight in the noble animal, who, in our days drew the chariot of the Sun, and now-a-days draws the chariot of Victoria, Queen of Great Britain and Ireland-God bless her !

$\begin{array}{cc} & \text { Castor } \\ \text { Olyupus, die Capricomi xx, } & \text { and } \\ \text { Anno Mundi 5852. } & \text { Pollux. }\end{array}$

PREFACE TO THE SECOND EDITION.

Nicholas Wiseman having been greedily swallowed by the Public, he is induced to offer them this Second Edition, under the auspices of Propagandism. 

THE

\title{
TRAINING AND EDUCATING
}

\author{
of \\ THE HORSE.
}

"Omne tulit punctum," says Horace, "qui Prefatory Obmiscuit utile dulci," - which a humorous friend of servations.

mine was wont to quote whenever he mixed a lump of sugar with his toddy.

If the utile and the dulce should happen to be mixed in the harmonious proportions of good punch in this little tract, the object of the writer will be fulfilled to his satisfaction, as he writes for amusement, having nothing else to do; like Lord Lauderdale's trees, which had nothing else to do but to

Trees grow without compliments being grow. Alas! his life has been "worn to the sere and paid to them. yellow leaf,"-he has no delight to pass away his time with hounds, horses, or balls, -not even a stall at the opera, nor a five guinea opera-glass wherewith to stare at the handsome women. 
The patriotic admonitions of his worthy countryman, Sharman Crawford, upon the doctrine of Tenant Right. "'meum," and tenant right, - the potatoe blight, and

Effects of Free Trade and Poor Laws in Ireland.

Glorious foresight of Bishop MicHale's disciples. all its concomitant charms, - the advantages of "free trade" to Ireland, as clearly propounded by the Times, and the Irish priests, - the admirable system of " English Poor Laws," engrafted upon a country whose people live like pigs, upon what Cobbett denominated "the soul-subduing root of indolence,"-the careful circumspection, foresight, and prudence, of the Irish tenants, who take the Rint in their pockets, to cultivate land in foreign climes, which they allow to grow waste and nourish weeds at home,-all these happy little combinations of circumstances, have left your poor Author, gentle - reader, with scarce one shilling to rub against another ; - and if he cannot afford to amuse himself in the field, and at the opera, he can afford an easy arm chair, a quire of threepenny post, pen and ink, a glass of gin twist, à la Byron, while inditing this treatise upon Horse Training. If it should happen that characters in high life are brought upon the tapis, let it be distinctly understood, that they are meant as noble illustrations of some text-as stars in the firmament ; and that nothing like offence is meant to be conveyed. When under the spiritual inspiGin-and-water ration of gin and water, it may perchance happen, and Lord Byron. that more unrestrained reins will be given to his imagination, than he would willingly allow to his 
horse. Whether his pen may become prurient, like that of Don Juan, from a similar cause, cannot at present be foretold; but should such happen, and any thing be written contra bonos mores-the fumes of gin must bear the whole blame, like the Irish potatoes. A poor woman of that country was asked by a barren Countess, anxious to probe to the bottom the secret of fecundity-" how she contrived to have such a numerous progeny?" "Faith, then," replied the poor peasant, "plaise your great Effects of Potatoes. ladyship, its the praties I blames for the whole of it."

If a man had stood up some forty years since and boldly asserted that he could produce a carProgress of Science in riage, or that a carriage would soon be invented, which could transport him fifty miles within the hour, he would be looked upon as a bedlamite.

Mr. Weld, who is I believe at present Secretary to the Dublin Society, gave to "La Societé des Mr. Weld and Steam Boats. Arts," at Geneva, in 1816, a wonderful account of himself and wife having made the first passage in a steain boat from Portpatrick to Donaghadee.The voyage of Columbus was a trifle to it.

Whenever Mr. Weld and wife were seen to walk the street, the learned Syndics (they are the savans and magnates of that famed republic, and bend the lumber vertebre of their republican backs to every Forty Years. Steam Boals. 
nobleman and filius nobilis, with as much flexibility as Sir Pertinax Macsycophant-and as to "hats off," Bishop Mac Hale would be delighted with First Voyage them, ) cried out "Voila, le grand Monsieur Weld,
of Columbus Weld. celui-la même qui a fait avec sa femme le trajet par mer de Port Patrique, en Irlande, jusqú à Donaghadée en Ecosse: quel courage de la part de pauvre Madame Weld, c'est au moins un trajet de vingt milles."

It was asked of me to give some other grand elucidation of the genius of Great Britain. My text was the shoeing of the horse, for the horses of Geneva were abominably shod. Being resolved to outdo my friend Weld in theory, if I could not do so in practice, I cried,_- "Bah! Monsieur Weld, quelle pauvre chose que ce petit trajet de vingt milles par mer," - "why the time is at hand when by the aid of steam we shall accomplish thousands and Prophecy by tens of thousands of miles upon the land, without the Autlior. the wear and tear of the horse or his shoes, in carriages upon trams constructed either of iron or of wood, something in the fashion that barrels are dispatched from one end of a brewery to the otherwhen every valley shall be exalted, and the hills laid low by tram roads - and when the fields shall be ploughed by steam; and as to the sea, we shall circumnavigate the globe by steam, and rob the winds of their proverbial fickleness." All this was 
very well for a bumpkin; however, my bold pro- Prophecy in phecy was thought worthy of being translated into Print, at French by Professor Pictet, and exists in one of the volumes of "La Societé des Arts de Geneve."

At a former period of my life I was a yachtsman, and a yacht builder, and had heard it gravely proved, or attempted to be proved, according to the doctrine of propulsion and resistance, that no ressel could ever be forced through the water at a greater velocity than fifteen knots an hour. It was also an established axiom, that the length of no vessel

Old theories on Ship Building. should be greater than four times or four times and a half her beam. I yesterday saw Mr. Scott Russell's "Queen of the Wave," whose length is seventeen times her breadth, and she is a clipper; and it is proposed, in a pamphlet just published, to build a steamer that shall go to America in fortyeight hours, and round the globe in fourteen days.

Round the World for Sport.

It may be looked upon as presumption in me to assert, that hitherto, since the days of Homer and No new Improvements in Horse training. the time of Virgil, no proper method has ever been adopted for perfectly training and educating the horse-we have followed the ancients and improved in nothing; - and the horse of the present day educates and trains himself through, and in despite of, the blunders of his trainers; and all the common sense of the matter lies on his side of the question. There can be no vanity in saying that I alone am 
the author of a new discovery, for mouthing and NewDiscovery educating the horse, and if this be vanity, it lies of Author. like the secret of Junius, within a narrow circlefor I write under the assumed name of a great Cardinal re- theologian, who aims at subjugating the human straints. mind to rules of obedience and restraint, such as are herein proposed for the thews and sinews of the horse; and let not the Reverend Gentleman take offence at this playful liberty with his name, for he may rest assured, that neither "sedition, privy conspiracy, or rebellion, false doctrine, heresy, or schism, hardness of heart, or contempt of " the Queen's commands, will result from our lucubrations.

Nothing new under the Sun.

Fifty Miles an Hour, and Boiling Potatoes, unknown to the Ancients.

Homer's Horses.
It is a common saying that "there is nothing new under the sun:" on the truth of that proverb it would be presumptuous to decide ; but I apprehend that going fifty miles within the hour in a steamcarriage is a modern invention, and that boiling potatoes was not known in Ireland before the time of Sir Walter Raleigh. However, there can be no doubt that uniting of the horse, and making him obedient to the hand of the coachman, was practised by the ancients more than three thousand years ago. Homer invites you, in the eighth book of the "Iliad," to look how beautifully the horses of Diomede stand upon the plain, and obey their charioteer.

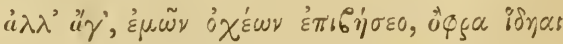

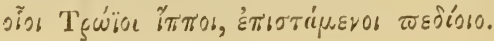


"Then haste, ascend my seat, and from the car

Observe the steeds of Tros, renowned in war ;"

and then adds, in a beautiful hexameter dactyl line, in which the sound just seems an echo to the sense, the qualities of their performance :-

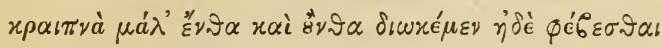

"Practis'd alike to turn, to stop, to chase,

To dare the fight, or urge the rapid race."

The modern art of lounging in the ring, and sawing the horse's mouth with a severe bit, if not practised in the time of Homer, was in full use

Circling and Lounging in the time of Virgil. amongst the Romans. They used a severe snaffle, which was known by the name of lupatum, from being jagged like the teeth of a wolf; and they began, as we of the present day, to lounge him in the circle at the age of three and four years. Virgil says-

"At tribus exactis ubi quatuor accesserat æstas;

Carpere mox gyrum incipiat gradibusque sonare Compositis, sinuetque alterna volumina crurum Sit que laboranti similis. Tum cursibus auras Provocet; ac per aperta volans, ceu liber habenis, Æquora, vix summâ vestigia ponat arenâ."

"But when to four full springs his years advance, Teach him to run the round, with pride to prance; And (rightly managed) equal time to beat, To turn, to bound in measure, and curvet. Let him to this, with easy pains be brought, And seem to labor, when he labors not; Thus, formed to speed, he challenges the wind, And leaves the Scythian arrow far behind; He scours along the field with loosen'd reins, And treads so light he scarcely prints the plains." 
Curvetting in olden times.

Buxton and

Fours-in-hand. friend Charley Buxton, was not an original Fourin-hand Man. Long before modern history, we learn-

"Primus Ericthonius currus, et quatuor ausus Jungere equos, rapidisque rotis insistere victor."

"Bold Ericthonius was the first who joined Four horses for the rapid race designed; And o'er the dusty wheels presiding sat."

Without entering into a theological or metaphysical argument, whether or not the horse has a soul, certain it is that he possesses a vast share of

Instinct of Horse near to reasoning. instinct, and often more common sense than his rider. That he is an accountable being is not contended, for all his vices are caused by man-he neither plots against the state, nor against the civil polity of his own species, and the most rigid divine cannot condemn him to purgatory for crimes which do not originate with himself. 
There are three avenues by means of which you can get at the understanding of the horse, and hold Avenues to Horse's underconverse with him, videlicet-by his ear, his eye, his mouth. Nothing pleases a horse more than being talked to in blandishing words, and to have his neck stroked-many there are who possess the same feelings; and for this reason, you will find horses very fond of ladies, who are generally in the habit of patting and coaxing them. Virgil says-

"Tum magis atque magis blandis gaudere magistri Laudibus, et plausæ sonitum cervicis amare."

"Soothe him with praise, and make him understand The loud applauses of his master's hand." standing.

There are many horses that exhibit much res- Influence of tiveness and bad temper with men, who will be Harses. most gentle and submissive to ladies.

Horses have the same facility of understanding language and the passions, expressed by the human Horse. Effects of the Voice upon the voice, that dogs possess. We all know how the voice of the huntsman checks the whole pack, when he calls out, in a determined voice, "Riot, war hare! have a care!" We need not be told to what perfection the training of different species of dogs is carried, through the medium of the human voice and gestures. I never was master of a horse 
for any length of time, whom I did not teach to walk, trot, or gallop, at my bidding. The use of a whip or spur was almost unknown to horses of my training.

At one time, a horse was in my possession, who would lift up all his feet as directed by me, and extend himself in attitude to be mounted.

Spanish

Muleter.
The Spanish muleteer drives his mules by his voice, and excites them into a trot or gallop by scolding. The lazy mule he makes suddenly start to her traces, by telling her, with a curse, that he will complain of her to the Blessed Virgin.

French Coach- To those who have seen the effect which the man.

driver of a French diligence produces on his horses, by mere colloquy, or who have ever witnessed the subserviency of the Arab horse to the voice of his master, little need be said on this part of our subject.

Knowledge of Horses by the Eyes.
The eye of the horse is placed in his head after the same fashion which nature has placed it in the head of the hare-he may be said to have an ubiquity of vision. There is no animal who makes the eye more subservient to acquiring knowledge, than the horse, or who expresses the passions more forcibly through that organ. Beware how you stand behind a vicious horse, while his eye is in 
"fierce frenzy rolling," in the hope that you are not in the axis of his sight.

To commence training the young horse, you must get complete possession of his eye, and show To commence Truining him, through that organ, that you mean him no harm, and are his friend. When he rolls his eye, plunges, kicks, and endeavours to get away, it is from some imaginary evil he has conjured up in his own mind. You must endeavour to make him sensible of his mistake, hy soothing and gentleness; should you imprudently flog him at this moment, you will induce him to associate the punishment with the cause of his alarm; and when the same cause again occurs, he will prepare to resist it with increased violence. We have nervous horses, as

Nervous Horses as well as Nervous Men.

well as nervous men-there is no accounting for animal organization. "Some men there are," says Shakspeare, "love not a gaping pig; some that are mad, if they behold a cat." You will find a nervous horse start at every leaf, and a nervous man start at his own shadow. Punishment will not disabuse the one, nor ridicule the other; you must allow both to convince themselves of the groundlessness of their apprehensions. Let no man call "shying" in a horse, vice; when he becomes vicious in shying, he is made so by a bad hand, and bad management; the rider, in this case, becomes more frightened than the horse. 
With a shying horse, the horseman should abandon his reins, and trust to his seat.

Sudden decision of the Horse.
Excitement caused by association.
The knowledge which the horse takes in by his eye, and his sudden decision upon that knowledge, is only known to those who have made the horse a study. They may be said to remember by the eye.

Horses have been in my possession, who not only knew their hunting day, but who would refuse their oats, and scour and stale, if I made my appearance on that morning in the stable in a red hunting frock. Formerly, when it was the fashion to appear at the cover side in the grey of the morning, a mare was in my stable, into whose manger the groom stole her oats through the darkness of night, for the appearance of an early candle would throw her into such excitement as to cause her to "break out" profusely, and to refuse her corn.

It happened to me, at one time, to drive an Irish hunter, which had the most incredible mania for the chase, under a heavily laden gig. We had got as far, before breakfast, as Petit France, on the road from Bath to Cheltenham. The ground was covered with snow at the time, and the road almost a sheet of ice. My horse's shoes having been "roughed," we proceeded on the journey after breakfast and two hours rest, very much against the advice of our host and the hostler, having de- 
termined on returning in case Master Baggot showed symptoms of distress. It was with difficulty I had urged him up the hill with the whip, and was upon the point of returning, and giving the matter up as a bad job-when, lo! my gentleman cocked his ears and tail, gave a snort, and proceeded to start off at a most rapid pace.

To me, the whole matter was most unaccountable, as to the cause of this new life and vigouruntil, having progressed about three miles, we came up with three old women on the top of a hill, dressed in red cloaks, after the fashion of that country. Mister Baggot passed them with a prance Effects of a Red Mantle. and a snort, and could scarcely be held in, while my lucky deliverers were receiving a couple of shillings, they being as much astonished at my liberality as I was with the effect of their scarlet mantles. Nor was this all-the horse actually retained the excitement for the remainder of the day, and brought me merrily into Cheltenham that evening, without a touch of the whip. His passion for following hounds was extraordinary. In the course of the chase he has fallen on his side, from

Passion of Horses for the

Chase. downright exhaustion, and when I dismounted and gave up the hunt in despair, my hero has risen, and after giving himself a shake, like a dog out of the water, and a good rubbing against me, as though I were a post, he has gone off at full gallop in the direction of the hounds. His confidence in my 
"hand" was such that I could make him take the most extraordinary jumps.

Offers to jump Upon one occasion, being very much bantered at
a five-barred Gate in a Dining-room. a sporting dinner, on my unwillingness to back my horse for a wager, as I am not a betting man, I offered to ride him over a five-barred gate in the room in which we were dining, for one hundred or two hundred guineas - the bet was not taken by any of the company.

This same horse has been for many years in the possession of Lord Fitzhardinge, and is, I believe, still alive, under the name of Dispute.

Mouth of Horses spoiled.

We now come to the horse's mouth. In many cases it were well for the poor animal that he had no mouth, and was led by the nose, as ladies are sometimes said to lead their husbands.

Many horses are entirely spoiled by their mouths being fretted in bad training; and the mouth, which, if properly managed, should be the medium of communicating the intentions and wishes of the rider to the horse, is made the source of annoyance to both parties. The horse says,- "Why do you saw my snaffle right and left through my mouth, until you establish a 'raw' on my lips? -mind that I tell you, when my 'raw' gets hard and callous I shall make you feel the consequences in my turn, Mr. Rider ;" and he keeps his word, for a callous mouth can never be subdued. 
The horse never knows what you want or mean Bad Methods. by suddenly bending his head upon his chest, with your "German rider" strapped upon his back, and forcing him forward when you mount him, with a pair of spurs at his sides, to make him throw the whole weight of his body upon the mouthing piece, with his head down, his shoulders in advance of his centre of gravity, and dragged forward in this position by a cord attached to a caveson.

The caveson pulls a horse down, and completely Use of Caveçon puts the whole weight of his body before his bad. shoulders. What does a cavegon teach a horse, but bad habits? We do not ride or drive him in a caveçon, he learns nothing in a caveson; it acts upon him as an instrument of terror, while strapped upon his nose: he ought to learn everything through his mouth. His mouth and bars are his hand and fingers, through which he learns to be guided. Did you ever see a recruit taught the goose step, with his head down, his shoulders bent forward, and pulled after the serjeant by a strap attached to an iron collar around his head? No: the serjeant does the very reverse; he puts the head up, he throws the shoulders back, he makes the legs to advance the body, he does not want the man to tumble on his nose.

You cannot elevate a horse's neck too much, so you do not throw his head up into the air, nor make him advance his forelegs too far before his body,- 
(like the majestic walk of a Spanish Andalusian lady) - causing them, as the drill serjeant does, to bring the body forward, instead of the body pushing the forelegs en avant.

How to carry the Head.

Practice of unskilful Trainer.

A well-broken horse should never carry his head down, but bended into a gentle curve at the extremity of a well set up neck. Every horse should be made to carry his head as nature has attached it to the cervical vertebræ of the spine. The curve given to his head should be no restraint upon his fore action.

The unskilful trainer endeavours to make every horse carry his head as though they all had naturally the same arched neck; and to effect this his mouth is tortured and sawed, until it becomes as callous as the hide of the rhinoceros. You cause the horse to pull at your hand, by first suddenly pulling at him, in your endeavours to make him carry his head in a way nature never intended he should-the strife begins with you. Let us show, as Hamlet did to his mother, the faulty picture, in showing how the horse is broken into harness in the present day, to say nothing of how he is broken for the saddle.

Wrong method of Breaking Horses for Harness.
All the great London horse dealers begin their training at the wrong end-they do not begin at the beginning. The unbroken colt, without the least previous knowledge of obeying the reins, or follow- 
ing his head when bended, is firmly lashed, to use a sailor's term, in a "Break," alongside a steady old horse, who, in point of fact, becomes his teacher. When the driver pulls the right rein, for the purpose of turning him to the right, the impression on his mouth and on his understanding is, that he is wanted to stop. If you tapped a recruit from behind, on the right shoulder, when he was marching from you, the man would halt, and would never think that you meant him to wheel with his left shoulder forward. Your sagacious coachman flogs the horse for not wheeling, and the horse resists the punishment by plunging and kicking, and this becomes his first lesson in kicking, which he is a long time in forgetting, especially if he smashes First Lesson in Vice is taught anything. "We have no more right," says Harry by Trainers.

Hieover, " to expect a horse to obey a mere pressure on his neck, till he is taught to know its import, than we should have a pressure on his hip; yet this is not only expected to be understood by the horse, but to be obeyed, in defiance of all he has been taught to the contrary." My rule is never to put Author's

a horse in harness until he is perfectly mouthed, System. and accustomed to obey the reins; he will then go quietly forward, keeping up to his traces, for there are very few horses naturally prone to "gib." So that my system of training ends where that in common use begins.

It is not my intention to give a history on horse 
training, or to publish to the world in this place my secret of bringing out the action of a horse, and making him obedient to the bridle; but I take upon me to state, in a few words, the simple fact, that I alone am the author, and possess the method of bringing out all the given action that a horse has been made capable of by nature; and that my system of training goes as far in advance of the method now in use, as the rail carriage of the present day surpasses the old four-horse coach.

Superior paces given.
I do not profess to give to a cart-horse the paces of a racer, but I profess to give to a cart-horse very different, and very superior action to what any other man, be he who he may, who does not possess my secret, can give him. As the late Brinsley Sheridan once said of himself : "If it is in him, to make it come out of him." For the horse's action is not cramped and confined by my lessons as in the manége ; on the contrary, all his action is brought out to perfection by the extreme working of his shoulder, and the natural position his head is placed in. I throw the entire muscles of his frame into gymnastics, under the government of his mouth. There is scarcely one horse in one hundred ridden in Rotten Row, who gallops true; having never been suppled and properly united, they cannot change their legs without the risk of falling, and are most unpleasant and uneasy in their paces. 
We daily see hundreds of horses in the Park, who move like cows, are all abroad in their action, heavy and boring on the hand, who never lead with the right leg, and do not know how to follow their heads.

The value of such horses is entirely lost by bad training. How to put them in a proper horseman- ${ }_{\text {Training. }}$. like manner into a gallop, to begin it, and finish well, displays the skill and elegance of the rider; but the horse must be well broken for the purpose. No lady or gentleman can effect such movements upon horses that are not properly united.

There must, of course, be a plus and minus organic excellence in all horses, as well as in recruits and ballet dancers; and my operations will only bring to perfection the capabilities of each horse, as the Drill Serjeant and the Maitre de Ballet effects upon the capabilities of their pupils.

In the whole of my manipulations, harshness or punishment is never used-a horse can scarce N. Wiseman's dominion over become vicious in my school-he learns with pleasure, and may be said to teach himself - and I can accomplish more in the mouthing and uniting of a horse in one month, than any other man can in six months' training, and that in a very superior style. By my method of putting a horse in harness for the first time, he is so completely under the the Horse. 
dominion of my hand, that to plunge or rear he cannot, and he knows when, by a pull of the rein, I want him to turn to the right or left, and has no option but to obey-no cause for a quarrel can arise between us. In short, the present system of horse training, which is founded upon ignorance and cruelty, will be completely revolutionized by my mode of training, whether for harness or saddle.

How Method originated.

These considerations were first forced upon my mind by the circumstance of having once bought a very magnificent thorough-bred horse, for what in slang language is called "a song;" he was sold, because nobody could hold him when his courage was up. Not wishing to undergo the drudgery of giving him a mouth, by daily working him with my hand on the road, a horse rider was employed to do so. This fellow brought home the horse every day with his mouth full of blood, but without any notion of bending himself to the right or the left,pull at either side, there he stood, like the Duke of Wellington's horse over the marble arch, and just as determined as the Duke himself at $W$ aterloo. When the horse's mouth got well from the abrasion, he was worse than ever. It then occurred to me that I must proceed with him in some other fashion than by lounging him in a caviçon, "more Romano:" with his head bent as a fixture upon his breast. 
Hunting gentlemen have often said, in my Mouth of hearing, that they did not like a hunter with too Hunters. fine a mouth ; in fact, they wanted to hold on by the bridle. Now, I never rode a hunter, who, when he disunited himself in his gallop, did not afford my hand sufficient support; nor have I ever heard a racing jockey complain of the too great fineness of his horse's mouth; in point of fact, no horse can be too well mouthed for a good horseman, and a bad horseman is much safer on the back of a well snaffled horse, than upon one which does not obey his bridle.

I never possessed a hunter whom I did not train to "passage right and left," and to wheel upon his centre like a well trained charger, and who was not always in my hand to bring him to his jumps as it pleased me, not as he willed, and to sidle up to allow a gate to be opened, or an obstruction to be removed from a gap. For such horses I have got long prices, because they were handy and understood their work.

There was an Irish horse trainer, who lived in my TheWhisperer. time, and who was known by the name of "The Whisperer." The man knew nothing whatever about mouthing or uniting a horse; his whole power lay merely in subjugating the animal to his will for the time, by mesmerism. There is some such natural quality inherent in myself; few horses 
are ever rude or vicious to me. Years gone by, an officer of the 60th Rifles, at Newport Barracks, Subjugates a in the Isle of Wight, thinking that a man in a
Vicious Horse. sailor's jacket had no business to know anything of horsemanship, laid me a wager of five pounds that I would not ride his horse round the camp field without being unseated: this same horse was in the habit of throwing every one but his master. Having got possession of the horse's attention, and coaxed and soothed him after my own fashion, I suddenly mounted, with the reins shortened in my left hand, and his head under command, after dragoon fashion, and then softening my hand, and encouraging him to go forward with my voice, and a slight pressure of the leg, the horse, to the astonishment of the "stante corona," who expected the fun of a spill of the blue jacket, took me quietly round the field.

I have seen the exhibitions of "The Whisperer," and they were looked upon as miraculous: he had the vanity of pretending to something superhuman, and carried his secret with him to the grave, leaving two sons to earn their livelihood as horse riders, who are of the same excellence in that profession as the many whom I call "Bull riders."

It may be thought presumptuous in me to compare myself to the great Sullivan, (parva componere magnis, ) for such was the name of "The Whisperer ;" but I take leave to say that I can effect per- 
manently, what the great sorcerer produced only for a limited period, and that a horse shall come out of my hands a very superior animal to what one ever came out of the hands of "The Whisperer."

There is no such thing as teaching what is known by the term "a good hand upon a horse,"Good Hand not Teachable. it is a gift of nature. Lord Anglesea possesses it in perfection, Uxbridge and Cardigan are not bad, and there is much to admire in the hand and seat of His Royal Highness the Duke of Cambridge.

I remember George IV., when Prince Regent, and before he became corpulent, riding down the Hand of George IV. line in a review. What elegance of hand and seat was there-"a station like the herald Mercury-a form and a combination where every god did seem to set his seal, to give the world assurance of a man :" nor let this picture be considered as overdrawn. He was a splendid gentleman, to make $A$ splendid which, was, in his own words, beyond the power of Gentleman. kings. Never had it been my lot, until then, to behold so noble-looking a man-such a sight "dans ma premiere jeunesse,"-made an impression upon me. In after life, occasions offered wherein I might have been the guest of his gracious Majesty, but some unlucky event was sure to intervene, for my birth has not been under a lucky planet; 
and I was never more known to my sovereign, than by a passing reverence, which accompanied my name at a levee or drawing-room, at one of which (in Ireland) he graciously signified his recollection of me. George the Fourth was always an object of my admiration, notwithstanding all the obloquy that has been cast upon him-

"The evil that men do, lives after them;

The good is oft interred with their bones."

He was a man of high accomplishments, and "beau coup d'esprit," and a constitutional king. The history of the greatest monarchs who have ever reigned, either male or female, (the present Queen of England excepted,) does not furnish materials for a book of morals.

Story of

Phaeton.

In the story of Phaeton, as given us in Ovid, the difficulty of a good hand is beautifully illustrated. Phœbus, yielding to the rash entreaties of his son, hands him over the reins of his fiery Handling of steeds, after repeated admonitions respecting the the Ribbons. management of their mouths. The horses soon discover the change of hand, cheek their bits and force their bridles, tear away helter-skelter, dash the chariot of the sun to atoms, and spill their inexperienced coachman, whose untimely end is thus recorded by the poet:-

"Hic situs est Phaeton, currus auriga paterni, Quem si non tenuit loris magnis tamen excidit ausis." 
I have never met with a Frenchman who had a

Count

D'Orsay.

good hand, or was a good horseman, save and except Count D'Orsay; but that chap is good at everything.

Strange ! very strange ! just as I write these lines, my servant brings me the Morning Post-D'Orsay is no more! D'Orsay has just been gathered to his forefathers. Alas! poor D'Orsay, he was a fellow of infinite talent, taste, and accomplishments, the beau ideal of elegance, the glass of fashion, and the mould of form- " Nihil erat quod non tetigit, quodcunque tetigit ornavit." D'Orsay is in his grave; " after life's fitful fever, he sleeps well, nor steel, nor poison, malice domestic, nothing can touch him further." They both lie in the same grave! let their sins be forgotten.

Blessington and D'Orsay. Amen!

The French sit completely home on the fork, with the toes down and the heels up, leaving the Seat of French on the Horse. muscles of the leg and thigh unbraced, to act as aids when required. They are like a sugar tongs astride upon a poker.

Strength of seat and power in the saddle, by means of a shortened stirrup, is what our dragoon Seat of English Dragoon. acquires after he has been previously well settled down on his fork in the riding school; and it was the superior seat arising from this cause, that Waterloo. 
enabled our "Heavies" to ride down Bonaparte's invincible Cuirassiers at Waterloo. Neither great firmness in the saddle, nor fineness of hand, can Seat of Jockey. be predicated of our Newmarket jockeys; they are obliged to ride in a bundle, in very short stirrups, with their feet quite home in the stirrup-iron, for the loss of the stirrup would be fatal in a race, and race horses never have fine mouths. Curiosity lately took me into a riding school, in Paris, to see if "they managed these matters better in France," French Riding as Sterne says. The riding master, finding I was Masters.

no spooney, took much pains to persuade me that the English knew nothing of horsemanship. He began caprioling upon a horse, which he held by reins, attached to a very severe bit, and by way of horsemanship making summersaults like the clown at Astley's. When I mounted his horse, and found that on the snaffle he had no more mouth than a pig, he ridiculed the idea of ever mouthing a horse on the snaffle, and ended the colloquy, by Gasconade telling me-"Mais Monsieur, pour l'art de bien Horsemanship. monter à cheval les Françaises surpassent tout le monde."

English

Dictionary by a Frenchman.

During the occupation of Paris, in 1815, my French master, who could not speak a word of intelligible English, told me he had a grand project in his head, to go to London to publish an English dictionary. "You havee not gotting," said he, 
"von bon dictionnaire Inglish. You have von dictionnaire from Johnson Bosvilé, un grand homme, he not know de Inglish grammaticalement."

Whether my French friend has ever illuminated England with his grand dictionnaire, I have yet to learn.

I once met Louis Napoleon in a hunting field. Never did I see a fellow get so many falls, nor rise Louis Nupoleon Hunting. again with so much courage. Every time he touched his mother earth, he rose from it, seemingly refreshed, like Antæus. There was that perseverance and determination shown in the hunting field, which has since enabled him to win the sceptre of France, and long may he hold it, for the peace of Europe and the subjugation of Socialism, balderdash liberty, (anarchy,) rapine, and idleness, founded upon the convenient doctrine, "Que la propriété est un vol."

Were it my province to command a regiment of cavalry, I would have the men and horses

Cavalry Drilled to Leaping. practised over the bar in the riding school, and regularly drilled to jumping. In 18-, we had a rebellion in the county of Cork, in Ireland, a "Rapale eruction," I believe. The gentlemen of the Muskerry Hunt enrolled themselves as a corps of yeomanry, and often had occasion to do duty with the Carabineers, in pursuit of the rebels 

Dragoons in- across the country. Upon those occasions, the
effectual in Pradial Wurfare. latter distinguished regiment was obliged to keep to the road, from the inability of their horses to jump, and were quite inefficient in this prædial Battle of Talavera. warfare. At the battle of Talavera an important charge of cavalry was brought to a stand by a small dyke: in the confusion the cavalry suffered much from the French infantry posted at the opposite side, and several officers and men, who had jumped the dyke, were made prisoners. Neither French nor German horses have the least notion of leaping, and it is certain that a trench four feet wide, or a wall or fence three feet high, would arrest their best mounted cavalry regiments. In my humble opinion, an order should be issued from the Horse Guards, that the men and horses of Her Majesty's cavalry regiments should be drilled at leaping.

Great Wurriors of Modern History bad Horsemen.
It is a curious coincidence, that none of our modern great warriors have been great horsemen; nor are the names of their chargers connected with the story of the achievements of their riders. How Julius Cæsar, or Alexander the Great rode, history does not mention; the name, however, of the horse of the latter, "Bucephalus," has been recorded, and Shakspeare has handed "White Surrey," the horse of Richard III., down to posterity. There is no mention made in the history of his 
battles, either of the horse or horsemanship of the Duke of Marlborough.

Our own great Duke (he will, I hope, pardon me) is not a good horseman; neither was his renowned but unsuccessful rival, whose legs, encased in great military boots, hung down at his horse's sides like jack puddings. I saw his favorite Arab, the horse he rode at Waterloo, in the Duke of Leuchtenberg's Bonaparte's Arab. stables; he stood about 14 hands 2 inches, and was then 28 years old. We have never heard much talk of the Duke of Wellington's charger at Waterloo; and yet, methinks, any such horse deserves a monument and epitaph as well as Lord Byron's dog, or NoBucephalus of the Great Duke of Wellington on General Fitzclarence's dog and horse, who repose under monumental fame in the parade field at Portsmouth. The great Duke, I am told, has hunted in Hampshire, and been seen to get falls, and to mount again with fresh pluckfor nothing on earth can frighten the man. I knew Bonaparte's stepson, Beauharnois, and rode with him; he was another of those indifferent horsemen, and always went at the rate of a hunt, "toujours ventre a terre," which the French call "bien monter a cheval." Murat, I believe, made himself as remarkable by good horsemanship, as by the character of being a "bon sabreur." Apropos "de bottes." Marshal Junot wanted to sell a horse to an English field-officer, who was Story of Marshal Junot. about to leave him in an exchange of prisoners: 
he recommended the horse, by saying that his shapes and beauty had so attracted his eye in battle that he rode at the rider, and sabred him. "But, General," said the English officer, "suppose you should again take the same fancy, when I am on his back-just think of my unhappy fate." "Ah," replied Junot, gravely, "sur cette affaire, mon ami, restez tranquillé, je ne sabre plus."

Ladies with a Good Seat.

As many

Hearts won at Rotten Row as at the Opera.

There is nothing so bewitching as noble horsemanship. That greatest of poets, from whom no secrets of nature were hidden, gives; as the grandest of accomplishments, "to witch the world with noble horsemanship." If it is bewitching in man, how much more so in woman. How many ladies have we known, who have won their husbands by a graceful seat, and a good hand upon a well united horse-elegant horsemanship in the Park has subdued as many hearts as graceful acting upon the stage.

Countess of Blessington

Could I but write a true history of Rotten Row, and D'Orsay. how splendidly would my tale be elucidated! Who is there that dees not remember the elegant horsemanship of the late Countess of Blessington-the Cleopatra of her day, who subdued the heart of her devoted Marc Antony, the finest horseman of his time? Who is there that has not felt the sensation made upon him by the horsemanship of elegantly- 
mounted ladies in the Park? The bizarre loves of a noble and daring soldier, himself a fine horseman, may be traced to his admiration of the hand and seat of fine women; and yet no lady can be a graceful rider who is not mounted on a well united horse. You may as well expect to see the tragedy of Hamlet well acted without the character of Hamlet. How it shocks me to see elegantly turned out ladies in other respects, except those abominable Jim Crow hats, mounted upon unbroken horses, who do not know how to put the right leg foremost, (for the left leg may be the right No "s showing off" upon shambling Horses. leg in a well united horse,) and jumble all their legs together in discordant paces, shaking the curls out of the locks of their lovely riders, and giving them most unbecomingly red faces. No horse that is disunited can go freely, there can be no harmony in his gaits; he will trot with the hinder legs, and gallop with his fore quarters-his whole movement will want ease and concord. Union helps and relieves the part of the horse which is weakest, so Union necessary. that, in point of fact, a horse that is well united will do his work with double the ease to himself of a horse that is all abroad and shambling in all his paces. Nothing, on the contrary, can equal the style and elegance of a lady well seated upon a well mouthed and united horse, carrying her reins Well turned out Lady on on a gauntlet-gloved left hand, the knuckles half turned up with a gentle curve of the wrist, the arm 
nearly reposing upon her left side, and the whip gracefully held in a dégagèe manner in the right Miss Quinten. hand-just as Miss Quinten used formerly to do " the thing." It is not my fashion to say anything that could hurt the feelings of innocent young women, in whatever rank of life they may be placed, for to say the truth, I am no tuft hunter; but I would caution my aristocratic readers not to Lolling on the imitate the careless loll, with the bridle in the right
Horse. hand, which may be assumed by dumpy girls, because they have a firm seat, and ride well united horses-their aristocratic appearance results from their horses; the careless loll, with the bridle in the wrong hand, may be indulged in by a tired foxhunter, but a lady should no more forget herself in the Park, by assuming an unbecoming attitude, than in a ball-room: and if she should, many are the satirical remarks that will be made upon her in the evening coteries of London.

Narrow Waists not becoming.

The shape of a woman is no where so defined and exalted as when dressed in a close fitting riding habit, and mounted on horseback; and we hope our fair readers will pardon the presumption of giving an opinion upon their angelic shapes, which is perhaps the opinion of most men. We do not like to see a woman with a waist like a wasp, or a toy with a small stalk connecting two large ends, called a Devil, played with a cord and two sticks. I 
should not like such a woman as the mother of my children.

A fine woman of my acquaintance, who laces Effects of herself into zero, perpetually gives birth to miserable Tight Lacing. abortions, unlike the fine looking father and mother ; while the poor-looking unlaced Irish peasant brings forth children of fine proportions. The contrast between the graceful figure of a fine young woman, in her loose every-day working dress, and her unContrast between Nature and Tight Lacing. naturally constrained shape, in tight-laced Sunday stays, is horribly conspicuous.

There are different theories as to the source of Burke and our admiration of what are acknowledged by the Alison upon human mind, to be the "lines of beauty" in Beauty. woman. Burke on the Sublime, and Alison upon Taste, refer those feelings to an instinctive impression that certain shapes and forms are best adapted by nature for carrying out her ends. How can a woman, who squeezes the capacity of her waist into half its natural and wholesome dimensions, be fitted to fulfil those duties she has been created to perform-to put the deformity it causes out of the question?

Without discussing the deformities occasioned by crooked spines and inverted ribs, caused by tight lacing, it may be observed that, as a matter of 
taste, unnaturally slender waists are not attractive. Men do not like abrupt angularity in the defined outlines of women-graceful oval lines are more

Waist of the Roman and Grecian Statues, and Callifesse Venus.

Relief from Tight Laciny. pleasing. We never find a miserable waist in the Roman or Grecian statues-every part of the human figure has in them its due proportions. The Callifesse Venus, although she abounds " $\mathrm{em}-$ bon-point," does not exhibit a disproportionately thin waist. What the French call "un corps svelte," does not mean Euclid's definition of a line, "length without breadth." How relieved must a tightlaced lady feel, when she delivers herself into the hands of her maid to be undressed, and goes off like a rocket! There have been some fine women, formerly known to me, who never wore stays, and when they made their appearance in a ball room, were particularly admired for the elegance of their shapes. And how delightful to support such women in a waltz, "where no stiffarched stays make meddling fingers ache ;" instead of clasping longitudinal rows of Mrs. Baily's whalebone, perfect non-conductors of the mesmerism of touch. Even Lord Byron could not be jealous of his "fair maid of Athens" waltzing in a Baily. A Lady well
dressed," and how pleasing to behold such natural figures, naturel." dressed in well fitting habits, and well brushed men's hats, (à bas les Jim Crows,) seated on horses united, and whose mouths are in correspondence with the hand. 
But, exclusive of the fascination of the mysterious "lines of beauty" in the fair sex, there is the Fascination of Complexion. fascination of the colours of the lovely rose and lily, which poets sing, and through which Mr. Rowland's Kalydor has realised for him a fortune ; and which become changed in their nature by tight lacing. These feelings may be equally said to have their origin in early association.

We associate the rose and the lily with the joyous life of Spring, and with fragile delicacy ; and why it is, Heaven only knows, that man is fascinated by evanescent beauty. Dr. Darwin, in his "Loves of the Plants," an amusing book, refers Dr. Darwin's Theory. the pleasure derived from the view of globular form, and white skin in the fair sex, to early association with those white orbs from which we draw our first nourishment.

We admire however, colours in woman, which we deprecate in man. It would be as abhorrent to Beauty of Men and Women-a see the delicate red and white of the rose and the lily, coupled with unpilosity, upon the cheeks and chin of a man, as to behold a dark skin and rough beard upon the face of a woman.

Vain, however, is the attempt to obtain beauty of complexion by art and cosmetics, if nature has not bestowed it. You may as well endeavour to wash 
Cosmetics injurious.

Colours from Tight Lacing.

Betty's rouge. glistening eyes, says, " La! Ma'am! what a beautiful complexion you have got, to take with you to the ball to night. You will be the envy of the room."

We must let our fair readers into a little bit of physiology upon this subject, if they understand it " a la bonne heure;" and if not, they must go to Mr. Faraday. the lectures of the learned Mr. Faraday, at the Royal Institution, who will enlighten them upon the said matter.

Complexion from the Blocd.

The blood derives its vermillion colour from the oxygen of the air we breathe; and to obtain that due portion of oxygen, the respiration of every healthy person should be free. We daily see unfortunate asthmatics, and those afflicted with malformation of the chest, of a livid complexion, because they cannot fill the cavity in which the lungs are placed with pure air; and the carbon in the blood not being duly thrown off in respiration, predominates in that fluid, and gives to the counten- 
ance the unhealthy livid and muddy colour of the drunkard and asthmatic.

The drunkard, by large doses of alcohol, supplies more carbon to the blood than his lungs can Lividity from what.

expel ; and the asthmatic cannot throw off his excess of carbon, because spasmodic affection prevents him dilating his lungs. Now this latter is exactly the case of every "tight laced" lady, who rides in the Park. When she breathes, the diaphragm cannot descend-the diaphragm is a great muscle which Effects of divides the cavity of the breast and lungs from the inferior cavity which she has laced into non-expansion; and it is the same case in the hot ball room, where, in a drum-braced-Baily, she is endeavouring, with great exertion, to keep the time of the odious and ungraceful "deux temps" waltz, while undergoing demi-strangulation from her stays.

There is no species of exercise which conduces more to health, and beauty of complexion, than exercise on horseback, because it combines, if the Complexion and Health from Horse Exercise. horse is educated, pleasing and harmonious movement through the air with cheerful spirits, which always seize upon a lady when seated upon a "well riding horse," a term which denotes good paces.How she expands her chest, and how her eyes glow with delight, and how all nature seems to her dressed in gayest habiliments, and how her own 
feelings are in unison with the glorious landscapewhen she is mounted upon her favorite, for the day's ride-especially if the object of her heart should at

Good temper and affection induced.

Infallible

School of

Nicholas

Wiseman.

Life and Motion by Electricity. the time happen to be her "cavaliero servante." On her return from this wholesome and joyous ride, with her nerves braced, and hilarity in her countenance, from inspiring the electricity of heaven, you will never catch her scolding the servants, or whipping the children, if she be married, and if single, all her heart is open to kindness and affection. To enjoy, however, the sublimity of those sensations, she must have a free and unrestrained action, in a well-made riding habit, and feel the poetry of motion upon a horse of Nicholas Wiseman's training, and be taught how to ride him in his school.

It has long been my opinion that, under the guidance of Omnipotence, electricity is the great agent which gives life and motion to animated ature-through it we move, and live, and have all things. Galvanism, magnetism, mesmerism, are all so many modifications of this great agent, and that gas, which chemists call oxygen, owes its power of supporting life and combustion to its faculty of embodying electricity, if I may use the expression. It is not given to us poor mortals, to reach at final causes, and we are only permitted to reason from effects. The motto which Voltaire has given to 
his Essay on Fire, may better be applied to electricity, as being, in my opinion, the proximate cause Voltaire's motto. of heat and light. "Electricitas (ignis) ubique latet, naturam amphectitur omnem, cuncta parat, renovat, alit."

To bring this ollâ podrida upon horse training, horsemanship, ladies' shapes, \&c., to a conclusion, it may be observed, that we write at no man, nor at any man's opinions, like the Times. Oh, the Times, the Times, the Times!!!- "quell temps"-one The glorious "Times," and day it is glorious sunshine on the head of Lord Derby, the " next day comes a frost, a chilling frost; and while he, good easy man, thinks full surely his honors are ripening, knips his roots." That Protean journal is as fickle as the winds, as changeable in its politics, praises, and censures, as the "varium et mutabile fomina." It is as prepos" terous for the Times to aim at writing down, contrary to common sense, law, and order, the upright a fickle JourLord Derby. Government of Lord Derby-as for ladies to endeavour at appearing attractive, "par excellence," in the Park, when mounted upon sorry jades, without ease in their paces, and correspondence between their mouths and the hands of their fair equestrians.

If this unpretending little jeu d'esprit will effect The Author no further good, than to persuade my fair country- $\begin{gathered}\text { changed to } \\ \text { Narcissus. }\end{gathered}$ 
women to give up the pernicious practice of tight lacing, I shall live, like Narcissus, in perfect love with myself; hoping that the ladies of the rising generation, who shall permit themselves to expand into their natural shapes, will erect a monument to their benefactor. The public shall be informed, Due Notice in due time, of the when and the where Nicholas given of Wiseman's School.

Wiseman will give his lessons and instructions upon the discipline of the horse.

The Duke of Wellington.

While this little tract has been progressing through the press, England has lost her greatest hero, whose name, however, has been mentioned herein with high respect and admiration.

FINIS. 



RBC

Fairman Rogers

798.7

$\omega 75$ 



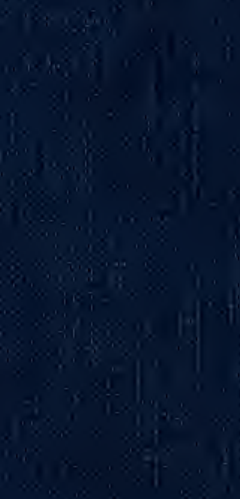

